\title{
Purification and Characterization of a New Thermostable, Haloalkaline, Solvent Stable, and Detergent Compatible Serine Protease from Geobacillus toebii Strain LBT 77
}

\author{
Wajdi Thebti, Yosra Riahi, and Omrane Belhadj \\ Laboratory of Biochemistry \& Technobiology, Faculty of Science of Tunis, Tunis El Manar University, \\ Farhat Hached University Campus, 2092 El Manar, Tunisia \\ Correspondence should be addressed to Omrane Belhadj; omrane.belhadj@fst.rnu.tn
}

Received 30 December 2015; Accepted 2 March 2016

Academic Editor: Pengjun Shi

Copyright (C) 2016 Wajdi Thebti et al. This is an open access article distributed under the Creative Commons Attribution License, which permits unrestricted use, distribution, and reproduction in any medium, provided the original work is properly cited.

\begin{abstract}
A new thermostable, haloalkaline, solvent stable SDS-induced serine protease was purified and characterized from a thermophilic Geobacillus toebii LBT 77 newly isolated from a Tunisian hot spring. This study reveals the potential of the protease from Geobacillus toebii LBT 77 as an additive to detergent with spectacular proprieties described for the first time. The protease was purified to homogeneity by ammonium sulfate precipitation followed by Sephadex G-75 and DEAE-Cellulose chromatography. It was a monomeric enzyme with molecular weight of $30 \mathrm{kDa}$. The optimum $\mathrm{pH}$, temperature, and $\mathrm{NaCl}$ for maximum protease activity were $13.0,95^{\circ} \mathrm{C}$, and $30 \%$, respectively. Activity was stimulated by $\mathrm{Ca}^{2+}, \mathrm{Mg}^{2+}, \mathrm{DTNB}, \beta$-mercaptoethanol, and SDS. The protease was extremely stable even at $\mathrm{pH} 13.25,90^{\circ} \mathrm{C}$, and $30 \% \mathrm{NaCl}$ and in the presence of hydrophilic, hydrophobic solvents at high concentrations. The high compatibility with ionic, nonionic, and commercial detergents confirms the utility as an additive to cleaning products. Kinetic and thermodynamic characterization of protease revealed $K_{m}=1 \mathrm{mg} \mathrm{mL}-1, V_{\max }=217.5 \mathrm{U} \mathrm{mL}^{-1}$, $K_{\text {cat }} / K_{m}=99 \mathrm{mg} \mathrm{mL}^{-1} \mathrm{~S}^{-1}, E_{a}=51.5 \mathrm{~kJ} \mathrm{~mol}^{-1}$, and $\Delta G^{*}=56.5 \mathrm{~kJ} \mathrm{~mol}^{-1}$.
\end{abstract}

\section{Introduction}

Thermophilic and hyperthermophilic organisms play a key role in the recent research and the enzymes produced by these microorganisms are coveted for applications in many areas. The proteases are some of the most commercialized enzymes with over $65 \%$ of total enzyme market [1]. They are used in various catalytic applications in both food and pharmaceutical industries. Nowadays, their roles in the synthesis of bioactive peptides and as additive in commercial detergents are gaining attention [2]. To be incorporated in the formulation of detergents, the protease must be active and stable in harsh washing conditions like high temperature, alkaline $\mathrm{pH}$, metal ions, and high salt concentrations in addition to stability and compatibility with surfactants and detergents $[3,4]$. They are used as additives instead of other chemicals harmful to the environment. Since the first alkaline protease Carlsberg produced by Bacillus licheniformis was commercialized as an additive to detergents in the sixties [5], research has emphasized trying and characterizing new proteases with better performance. Several proteases have been purified and characterized from Bacillus circulans DZ100 [6], Streptomyces sp. AB1 [7], Bacillus subtilis AP-MSU6 [8], Bacillus sp. EMB9 [9], and Geobacillus caldoproteolyticus [10]. The industrial demand of highly active and stable proteases continues to rise and various attempts have been made to enhance stability of alkaline proteases by site directed mutagenesis and protein engineering but the screening of microorganisms from extreme habitats seems to be the best approach. Also in this study a protease from Geobacillus toebii LBT 77 isolated from a Tunisian hot spring was purified and characterized.

\section{Materials and Methods}

2.1. Substrates and Chemicals. Unless otherwise specified, all substrates, chemicals, and reagents were purchased from Sigma-Aldrich (Saint Louis, Missouri, USA).

2.2. Microorganism. The strain Geobacillus sp. LBT 77 producing alkaline proteases was isolated from the hot spring 
"Hammam El Atrous" next to the Ichkeul lagoon in Bizerte, Tunisia $\left(37^{\circ} 08^{\prime} 18.8^{\prime \prime} \mathrm{N}, 9^{\circ} 41^{\prime} 24.7^{\prime \prime} \mathrm{E}\right)$. The strain was identified based on the phenotypic characteristics of the Bacillus genus and phylogenetic analysis of the $16 \mathrm{~S}$ rDNA sequence. Genomic DNA was extracted as described by Marmur [11] and $16 \mathrm{~S}$ rRNA gene sequences were amplified using the bacterial universal primers 16SF (5'AGAGTTTGATCCTGG$\mathrm{CTCAG}^{\prime}$ ) and 16SR (5'CTACGGCTACCTTGTTACGA3') [12] using the following PCR program: 1 cycle of $94^{\circ} \mathrm{C}$ for $5 \mathrm{~min}, 30$ cycles of $94^{\circ} \mathrm{C}$ for $1 \mathrm{~min}, 54^{\circ} \mathrm{C}$ for $1 \mathrm{~min}$, and $72^{\circ} \mathrm{C}$ for $1.5 \mathrm{~min}$, and a cycle of $72^{\circ} \mathrm{C}$ for $5 \mathrm{~min}$. The amplified products were purified and the sequence of the $16 \mathrm{~S}$ rRNA gene was determined by Sanger method DNA sequencing (ABI 3730xl DNA analyzer, USA). Sequence comparison with the databases was performed using BLAST program through NCBI website. A phylogenetic tree was constructed with MEGA version 6.06 using the neighbor-joining method.

2.3. Screening and Production of Protease Activity. Screening of protease activity was performed by the method of dissemination through wells on milk agar medium at $\mathrm{pH} 9$ containing $5 \mathrm{~g} / \mathrm{L}$ tryptone, $3 \mathrm{~g} / \mathrm{L}$ yeast extract, $15 \mathrm{~g} / \mathrm{L}$ agar, and $25 \mathrm{~mL}$ skimmed milk. $60 \mu \mathrm{L}$ of an $18 \mathrm{~h}$ bacterial culture was injected into each well and the plates were incubated for $18 \mathrm{~h}$ at $55^{\circ} \mathrm{C}$. Protease activity was confirmed by the appearance of a clear zone around the well-testifying degradation of casein milk [6]. Production of protease by Geobacillus toebii LBT 77 was carried out at $\mathrm{pH} 8$ in a medium containing $5 \mathrm{~g}$ bactopeptone, $5 \mathrm{~g}$ yeast extract, $5 \mathrm{~g} \mathrm{NaCl}, 10 \mathrm{~g}$ gelatin, and $0.2 \mathrm{~g} \mathrm{CaCl}_{2}$ in $1 \mathrm{~L}$ deionised water [9]. Inocula were routinely grown in Tryptic Soy Broth (Scharlau, Spain) medium. Media were autoclaved at $120^{\circ} \mathrm{C}$ for $20 \mathrm{~min}$. Cultures were performed on a rotator shaker $(150 \mathrm{rpm} / \mathrm{min})$ for $96 \mathrm{~h}$ at $55^{\circ} \mathrm{C}$, in $500 \mathrm{~mL}$ Erlenmeyer flasks with a working volume of $100 \mathrm{~mL}$. Growth was followed by measuring the optical density at $600 \mathrm{~nm}$ every $6 \mathrm{~h}$. The culture medium was centrifuged at $12000 \mathrm{rpm}$ for $20 \mathrm{~min}$ at $4^{\circ} \mathrm{C}$ and the cell-free supernatant was used as a crude extract for estimation of proteolytic activity.

2.4. Assay of Protease Activity. Proteolytic activity was determined by using casein as substrate. One $\mathrm{mL}$ of casein $10 \mathrm{~g} / \mathrm{L}$ in $50 \mathrm{mM}$ glycine- $\mathrm{NaOH}$ buffer $\mathrm{pH} 11$ was mixed with $900 \mu \mathrm{L}$ of glycine-NaOH. Reaction was initiated by the addition of $100 \mu \mathrm{L}$ of enzyme and the tubes were placed in a water bath at $70^{\circ} \mathrm{C}$. After $20 \mathrm{~min}$ of incubation, $2 \mathrm{~mL}$ of $10 \%$ TCA was added to stop the reaction. The reaction mixture was centrifuged at $12000 \mathrm{rpm}$ for $10 \mathrm{~min}$ and absorbance was measured at $280 \mathrm{~nm}$ [13]. One unit of proteolytic activity was defined as the amount of enzyme required to release $1 \mu \mathrm{g}$ of tyrosine per minute under experimental conditions.

\subsection{Enzyme Purification}

2.5.1. Ammonium Sulfate Precipitation. Cell-free supernatant was collected by centrifugation at $12000 \mathrm{rpm}$ for $20 \mathrm{~min}$ at $4^{\circ} \mathrm{C}$ after $72 \mathrm{~h}$ of cultivation. Ammonium sulfate was slowly added to the supernatant to $80 \%$ saturation and the mixture was incubated overnight at $4^{\circ} \mathrm{C}$. The precipitate was collected by centrifugation, dissolved in a minimal volume of $25 \mathrm{mM}$ Tris- $\mathrm{HCl}$ ( $\mathrm{pH} 8.5)$, and dialyzed against three changes of the same buffer for $24 \mathrm{~h}$.

2.5.2. Sephadex G-75 Gel Filtration. The dialysate was subjected to gel filtration on Sephadex G-75 column $(2.1 \mathrm{~cm} \times$ $50 \mathrm{~cm}$ ) equilibrated with $25 \mathrm{mM}$ Tris- $\mathrm{HCl}(\mathrm{pH} \mathrm{8.5).} \mathrm{The}$ column was eluted with the same buffer at a flow rate of $20 \mathrm{~mL} / \mathrm{h}$, and fractions of $3 \mathrm{~mL}$ were collected and then analyzed for protease activity and protein concentration. The active fractions were pooled and subjected to ion exchange chromatography.

2.5.3. DEAE-Cellulose Ion Exchange Chromatography. This round was performed by applying active fractions from the previous step to a DEAE-Cellulose $(2 \mathrm{~cm} \times 25 \mathrm{~cm})$ equilibrated with $25 \mathrm{mM}$ Tris- $\mathrm{HCl}$ ( $\mathrm{pH} 8.5$ ). Bounded proteins were eluted with a linear gradient of $\mathrm{NaCl}$ from 0 to $1 \mathrm{M}$ at a flow rate of $50 \mathrm{~mL} / \mathrm{h}$ and analyzed for protease activity.

All purification steps were performed at $4^{\circ} \mathrm{C}$. The protein content of each chromatographic fraction was determined by measuring the absorbance at $280 \mathrm{~nm}$.

2.6. Protein Estimation. Protein concentration was determined by the colorimetric method of Bradford [14] using bovine serum albumin as standard.

2.7. Polyacrylamide Gel Electrophoresis and Zymography. SDS-PAGE was carried out to determine the purity and molecular weight of the enzyme as described by Laemmli et al. [15] using 5\% (w/v) stacking and $12 \%(\mathrm{w} / \mathrm{v})$ separating gels. Protein bands were visualized by staining with Coomassie Brilliant Blue R-250. The molecular weight of the enzyme was estimated using a low-molecular weight calibration kit (Biomatik Co., Canada) as markers.

Zymography was performed by the method of GarciaCarreno [16] to confirm the enzyme activity. After electrophoresis, the gel was immersed in $100 \mathrm{mM}$ Tris-HCl buffer (pH 8.5) containing $2.5 \%$ Triton X-100 at $4^{\circ} \mathrm{C}$, with shaking for $30 \mathrm{~min}$ to remove SDS; then, the gel was washed twice with $100 \mathrm{mM}$ Tis-HCl buffer ( $\mathrm{pH} \mathrm{8.5)} \mathrm{in} \mathrm{order} \mathrm{to} \mathrm{eliminate}$ residual Triton $\mathrm{X}-100$ and then incubated with $1 \%(\mathrm{w} / \mathrm{v})$ casein in $100 \mathrm{mM}$ Tris- $\mathrm{HCl}\left(\mathrm{pH} \mathrm{9.5)}\right.$ at $75^{\circ} \mathrm{C}$ for $60 \mathrm{~min}$. Finally, the gel was stained using Coomassie Brilliant Blue $\mathrm{R}-250$. Appearance of a clear halo zone on the dark-blue background indicates the presence of enzyme.

\subsection{Biochemical Properties of the Purified Protease}

2.8.1. Effects of Temperature, $\mathrm{pH}$, and $\mathrm{NaCl}$ on Enzyme Activity and Stability. To study the effect of temperature on activity of the purified enzyme, the reaction mixture was incubated at different temperatures ranging from 55 to $120^{\circ} \mathrm{C}$. Enzyme activity was measured as described earlier. Thermal stability was evaluated by incubating the purified enzyme at 70,80 , 90 , and $95^{\circ} \mathrm{C}$ for $180 \mathrm{~min}$ in the presence and absence of $5 \mathrm{mM}$ $\mathrm{CaCl}_{2}$. Residual activity was measured at $95^{\circ} \mathrm{C}$ and $\mathrm{pH} 13$. The activity of nonheated enzyme was considered as $100 \%$. 


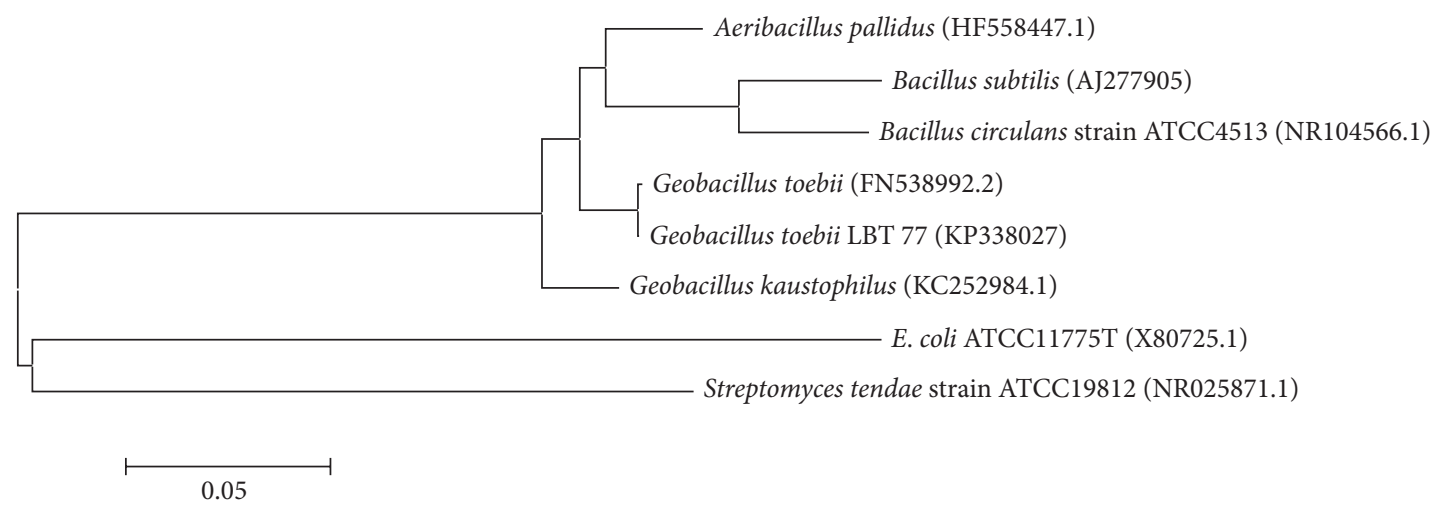

Figure 1: Phylogenetic tree based on 16S rRNA gene sequences, drawn using the neighbor-joining method and showing the relationship between Geobacillus toebii LBT 77 and species from genera Bacillus and Geobacillus. E. coli and Streptomyces tendae were used as out groups.

Effect of $\mathrm{pH}$ was determined by varying the $\mathrm{pH}$ of the reaction mixture using the following buffers: $(100 \mathrm{mM})$ glycine- $\mathrm{HCl}, \mathrm{pH}$ 2.0-5.0; potassium phosphate, $\mathrm{pH}$ 6.0-7.0; Tris- $\mathrm{HCl}, \mathrm{pH}$ 8.0-8.5; glycine- $\mathrm{NaOH}, \mathrm{pH} 9.0 ; \mathrm{NaHCO}_{3}$ $\mathrm{NaOH}, p H$ 9.5-10-11; $\mathrm{NaH}_{2} \mathrm{PO}_{4}-\mathrm{NaOH}, \mathrm{pH}$ 11.5-12; KCl$\mathrm{NaOH}, \mathrm{pH}$ 12,5-13-13.5-13.75. To test $\mathrm{pH}$ stability, the enzyme was preincubated in various buffer solutions $(\mathrm{pH} 6-$ 13) for $12 \mathrm{~h}$ at $60^{\circ} \mathrm{C}$. The residual enzyme activity was then determined at the optimum conditions of assay.

Effect of $\mathrm{NaCl}$ was carried out by incubating the reaction mixture at different concentrations of $\mathrm{NaCl}(0-40 \%)$. Stability was investigated by preincubating the enzyme for $1 \mathrm{~h}$ at different concentrations of $\mathrm{NaCl}(0-40 \%)$ and residual activity (\%) was measured at the optimum conditions of assay.wa

\subsubsection{Effects of Inhibitors and Metallic Ions on Activity of} Protease. Effect of protease inhibitors such as phenylmethylsulfonyl fluoride (PMSF), ethylenediaminetetraacetic acid (EDTA), dithio-bis-nitrobenzoic acid (DTNB), and $\beta$-mercaptoethanol was determined at 5 and $10 \mathrm{mM}$ by measuring relative activity after preincubating the enzyme for $30 \mathrm{~min}$ at $55^{\circ} \mathrm{C}$. The activity at standard conditions without additives was considered as $100 \%$ [2]. Effect of metal ions on enzyme activity was investigated at $5 \mathrm{mM}$ by adding divalent $\left(\mathrm{Zn}^{2+}\right.$, $\mathrm{Fe}^{2+}, \mathrm{Mg}^{2+}, \mathrm{Mn}^{2+}, \mathrm{Ca}^{2+}, \mathrm{Cu}^{2+}, \mathrm{Hg}^{2+}$, and $\mathrm{Co}^{2+}$ ) and monovalent $\left(\mathrm{Na}^{+}, \mathrm{K}^{+}, \mathrm{Al}^{+}\right.$, and $\left.\mathrm{Li}^{+}\right)$ions to the reaction mixture. Relative activities were estimated versus activity without any metallic ions after $1 \mathrm{~h}$ of incubation at $55^{\circ} \mathrm{C}$.

2.8.3. Effect of Detergents on Enzyme Activity. Anionic (SDS), cationic (CTAB), and nonionic detergent (Triton X100) were preincubated with enzyme for $60 \mathrm{~min}$ at $55^{\circ} \mathrm{C}$ and residual activity was determined. Effect of commercial detergent (OMO, Ariel, and Nadhif) on protease activity was studied with $1 \%(\mathrm{w} / \mathrm{v})$ solution of detergent. The enzyme was preincubated with the aforementioned detergents at $50^{\circ} \mathrm{C}$ for $1 \mathrm{~h}$ and then assayed for protease activity.

2.8.4. Effect of Organic Solvents on Protease Activity. The enzyme was mixed with 25 and $50 \%$ of many organic solvents such as cyclohexane, n-butanol, ethanol, toluene, acetonitrile, acetone, isopropanol, methanol, and benzene for $4 \mathrm{~h}$ at $55^{\circ} \mathrm{C}$.

2.9. Catalytic and Thermodynamic Parameters. Kinetic parameters were determined by assaying protease activity against various casein concentrations under optimized assay conditions. $V_{\text {max }}, K_{m}, K_{\text {cat }}$, and $K_{\text {cat }} / K_{m}$ were calculated using a Lineweaver-Burk plot $(1 / V$ versus $1 /[S])$. Thermodynamic parameters for casein hydrolysis, activation energy, enthalpy, entropy, and free energy of activation were calculated as per Akolkar and Desai [17].

All experiments mentioned above were repeated at least three times, and each value represents the average of three repetitions.

\section{Results and Discussion}

3.1. Microorganism. From a collection of 161 bacteria, 37 caseinolytic strains were isolated. Among these strains, the strain LBT 77 exhibited a large clear zone of degradation showing high protease activity. Phylogenetic analysis of its $16 \mathrm{~S}$ rRNA gene sequence indicated that the strain LBT 77 is affiliated to Geobacillus and is closest to Geobacillus toebii (99\% homology) (Figure 1). The sequence has been deposited in the EMBL/GenBank/DDBJ databases under accession number KP338027.

3.2. Production of Extracellular Protease. Protease production is proportional to bacterial growth; in fact, the maximum production coincides with the end of the stationary phase $(1900 \mathrm{U} / \mathrm{mL})$ at $42 \mathrm{~h}$ of incubation (Figure 2). This result is consistent with reports in the literature $[2,18,19]$.

3.3. Purification of Protease. The protease present in the crude extract was purified using ammonium sulfate $80 \%$ followed by Sephadex G-75 and DEAE-Cellulose (Figure 3). Table 1 indicated that the protease was purified to 5 -fold with specific activity of $739.5 \mathrm{U} / \mathrm{mg}$. The reduction of recovery (\%) from one step to the other is due to the elimination of some lower specific activity during chromatography as reported previously [20]. 
TABLE 1: Purification of protease from Geobacillus toebii LBT 77.

\begin{tabular}{|c|c|c|c|c|c|}
\hline Purification step & $\begin{array}{c}\text { Total activity } \\
\text { (U) }\end{array}$ & $\begin{array}{c}\text { Total protein } \\
(\mathrm{mg})\end{array}$ & $\begin{array}{c}\text { Specific activity } \\
(\mathrm{U} / \mathrm{mg})\end{array}$ & Recovery (\%) & Purification fold \\
\hline Crude enzyme & 11357 & 171.5 & 66.5 & 100 & 1 \\
\hline Ammonium sulfate precipitation & 8064 & 45 & 180 & 71 & 1.5 \\
\hline Sephadex G-75 & 2504 & 7 & 348 & 22 & 4.5 \\
\hline DEAE-Cellulose & 2292.5 & 3 & 739.5 & 20 & 5 \\
\hline
\end{tabular}

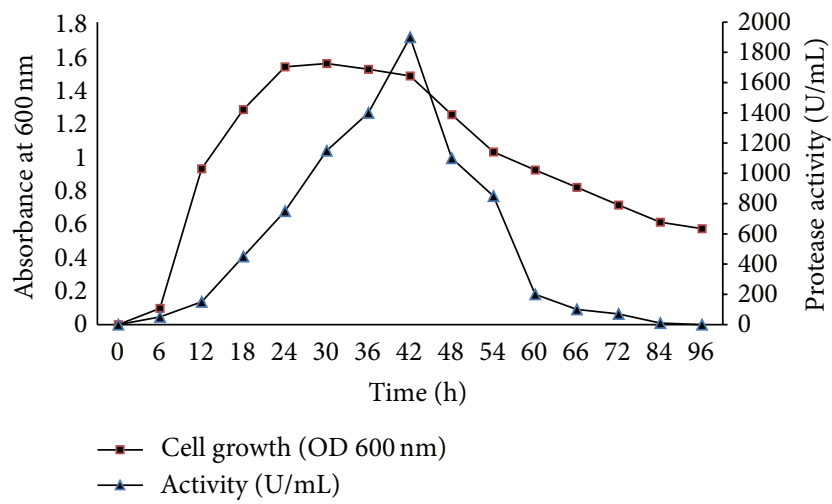

FIGURE 2: Growth kinetics and protease production of Geobacillus toebii LBT 77.

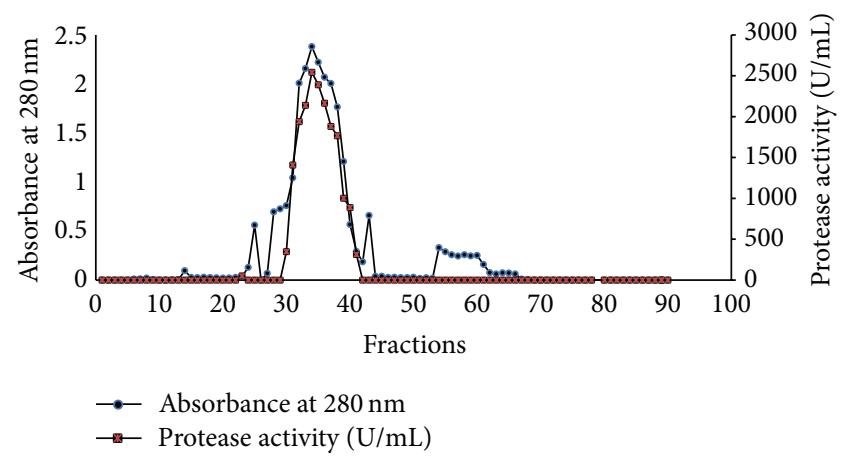

FIGURE 3: Elution profile of protease from Geobacillus toebii LBT 77 on Sephadex G-75 gel filtration chromatography.

3.4. Polyacrylamide Gel Electrophoresis and Zymography. The purified protease appeared as a single band on the SDS-PAGE with a molecular weight of approximately $30 \mathrm{kDa}$ (Figure 4). Mostly, the molecular weights of bacterial proteases are between 15 and $40 \mathrm{kDa}$. The molecular weight of the protease produced by LBT 77 was lower than those of the Bacillus pumilus CBS $(34,5 \mathrm{kDa})$ [21] and Bacillus circulans DZ100 $(32 \mathrm{kDa})[6]$ and higher than those of the proteases from Bacillus mojavensis A21 (20 kDa) [22] and Bacillus subtilis PE11 (15 kDa) [23].

The zymogram analysis showed a clear band against a blue background indicating the purity and the monomeric form of the protease.

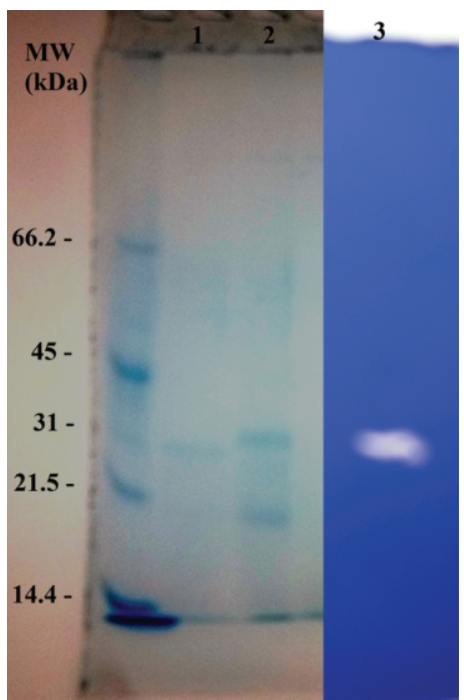

FIGURE 4: SDS-PAGE and activity staining of purified G. toebii LBT 77 protease. Lane 1: purified proteases after DEAE-Cellulose; Lane 2: proteases purified by sephadex G75; Lane 3: zymogram of purified protease.

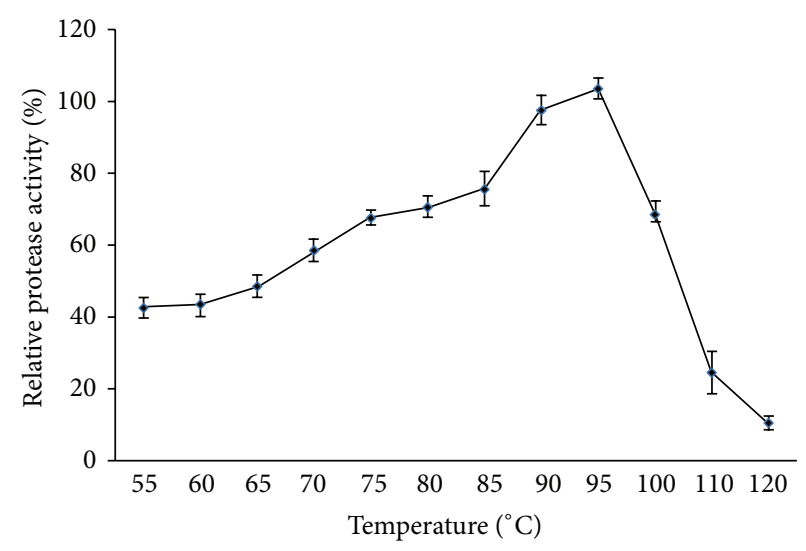

FIGURE 5: Effect of temperature on protease activity.

\subsection{Biochemical Properties of the Purified Protease}

3.5.1. Effects of Temperature, $\mathrm{pH}$, and $\mathrm{NaCl}$ on Enzyme Activity and Stability. The enzyme was active between 70 and $100^{\circ} \mathrm{C}$ with an optimum of $95^{\circ} \mathrm{C}$ (Figure 5). Relative activities at 85,90 , and $100^{\circ} \mathrm{C}$ were about 72,94 , and $65 \%$, respectively. An optimum of temperature at $95^{\circ} \mathrm{C}$ was reported for the protease from Bacillus sp. MLA64 [24]. 


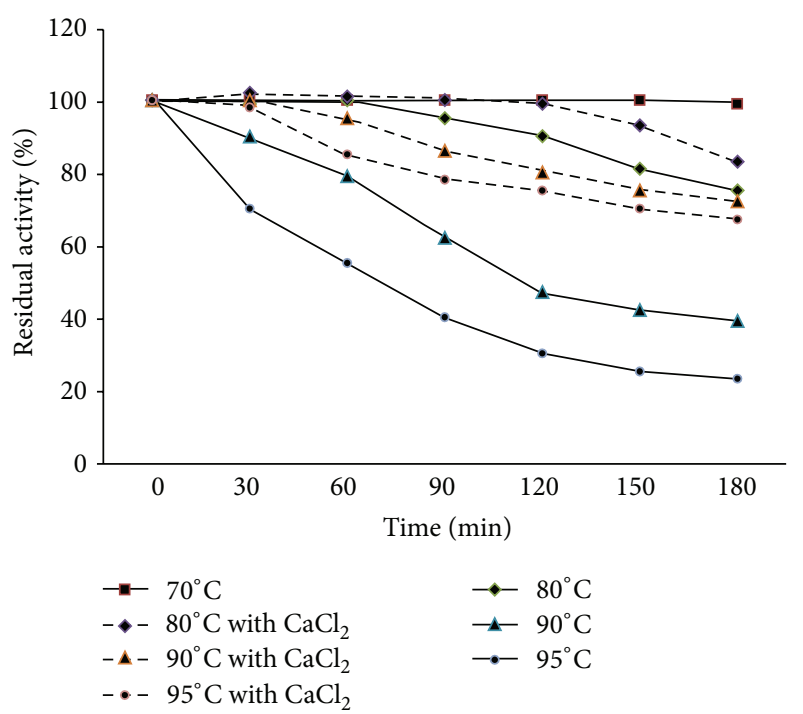

FIGURE 6: Effect of temperature on protease stability.

The protease in this study was also found to be completely stable at temperatures lower than $80^{\circ} \mathrm{C}$ after $180 \mathrm{~min}$ of incubation (Figure 6). Half-life of the enzyme at $95^{\circ} \mathrm{C}$ was estimated to be $70 \mathrm{~min}$. This is higher than those of other proteases which retain a lower amount of their initial activity even in a shorter period of incubation and also at lower temperatures. $\mathrm{Ca}^{2+}$ increased thermal stability of the enzyme since it retained $67 \%$ of the original activity after incubation at $95^{\circ} \mathrm{C}$ for $180 \mathrm{~min}$. The effects of $\mathrm{Ca}^{2+}$ on thermal stability of proteases were previously reported [25].

The enzyme showed maximum activity at $\mathrm{pH} 13.0$ and was highly active in the $\mathrm{pH}$ range of 9.0 to 13.25 . Indeed, the enzyme shows $62 \%$ and $80 \%$ of its activity at $\mathrm{pH} 9$ and 13.25 , respectively (Figure $7(\mathrm{a})$ ). These findings indicate that this enzyme belonged to alkaline proteases group. The particularity of this enzyme is its $\mathrm{pH}$ optimum of activity. In fact, most alkaline proteases listed in the bibliography have optimum $\mathrm{pH}$ that does not exceed $\mathrm{pH} 12[26,27]$. The enzyme was stable between $\mathrm{pH} 8$ and 13 and retained about $99 \%$ of its activity after incubation at $50^{\circ} \mathrm{C}$ for $12 \mathrm{~h}$ (Figure $7(\mathrm{~b})$ ). These characteristics are important for its use as laundry additive [28].

The protease activity has risen by increasing $\mathrm{NaCl}$ concentration until an optimum of 30\% and has decreased at higher concentration. The same optimum concentration was observed for the protease produced by Bacillus alveayuensis CAS 5 [29]. Halotolerant proteases are interesting for biotechnological applications, especially in detergent industry, and this one was completely stable at $20 \%$ and retained $80 \%$ of activity at $30 \%$ of $\mathrm{NaCl}$ (Figure 8). This was higher than the protease of Bacillus aquimaris VITP 4 [19] which was stable up to $12 \%$ and lower than this of Bacillus alveayuensis CAS 5 [29] which was stable up to $25 \%$.

3.5.2. Effect of Inhibitors and Metal Ions on Activity of Protease. The effect of inhibitors and chelators on proteases activity showed that PMSF strongly inhibits the activity to $20 \%$ and $5 \%$ at 5 and $10 \mathrm{mM}$, respectively (Figure 9).

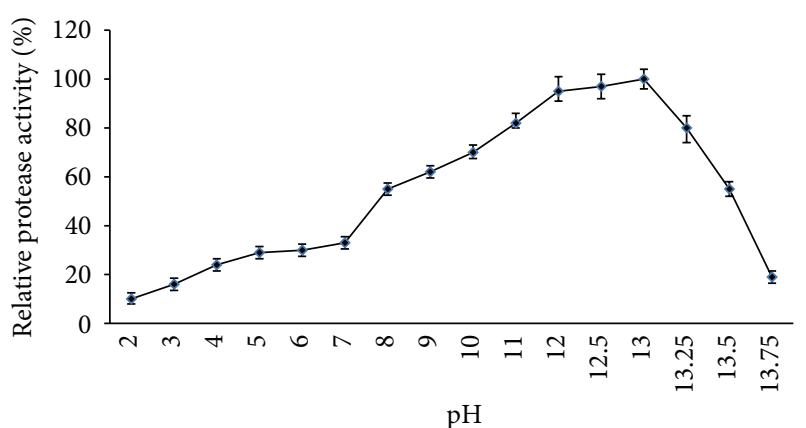

(a)

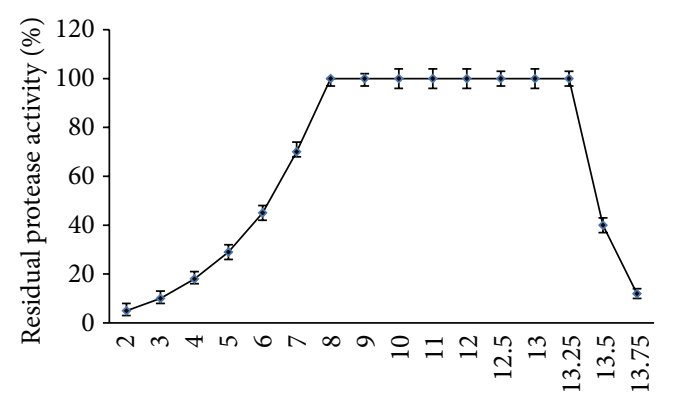

$\mathrm{pH}$

(b)

FIGURE 7: Effect of $\mathrm{pH}$ on protease activity (a) and stability (b).

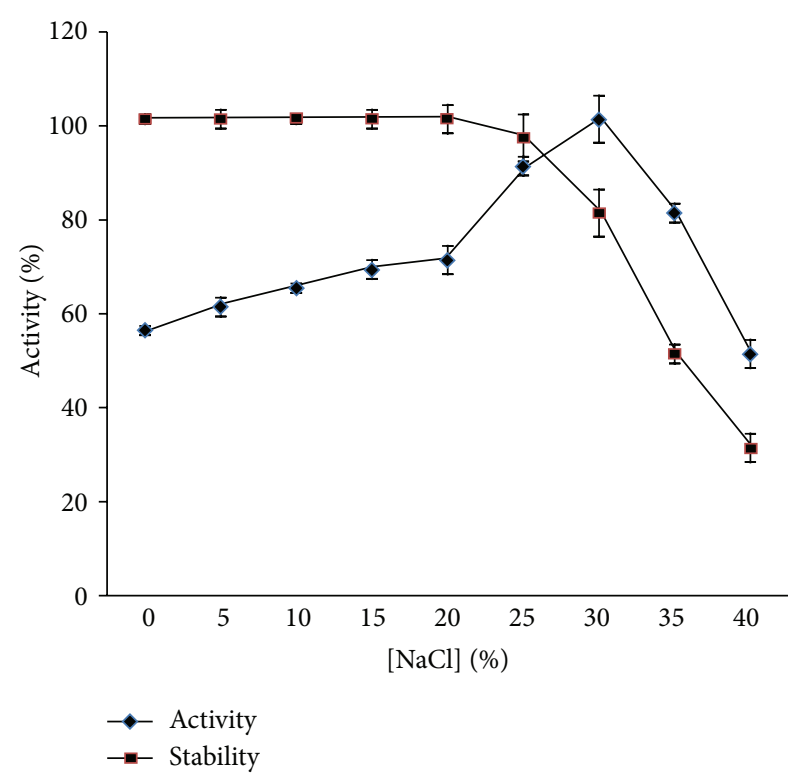

FIGURE 8: Effect of $[\mathrm{NaCl}]$ on protease activity and stability.

This confirms its belonging to the group of serine proteases $[25,30]$. Among the tested inhibitors, activity was increased by DTNB and $\beta$-mercaptoethanol suggesting that it is a thiol-depending serine protease [25]. The metalloproteases inhibitor EDTA inhibited activity by $22 \%$ at $10 \mathrm{mM}$; similar result was reported earlier in serine protease produced by Bacillus licheniformis [31]. Regarding the effect of metal ions, the activity was enhanced with $\mathrm{Mg}^{2+}$ and $\mathrm{Ca}^{2+}$ (Figure 10). 


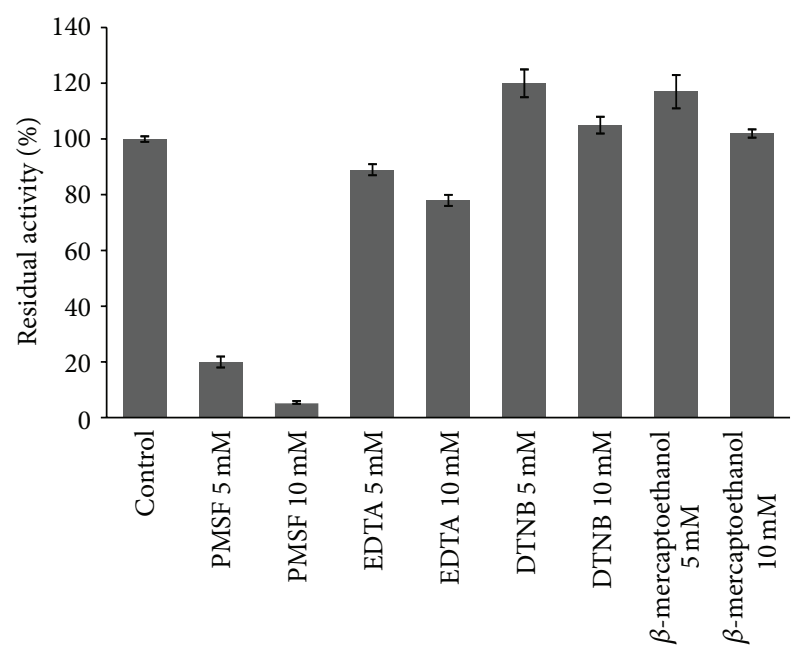

FIGURE 9: Effect of protease inhibitors on enzyme activity.

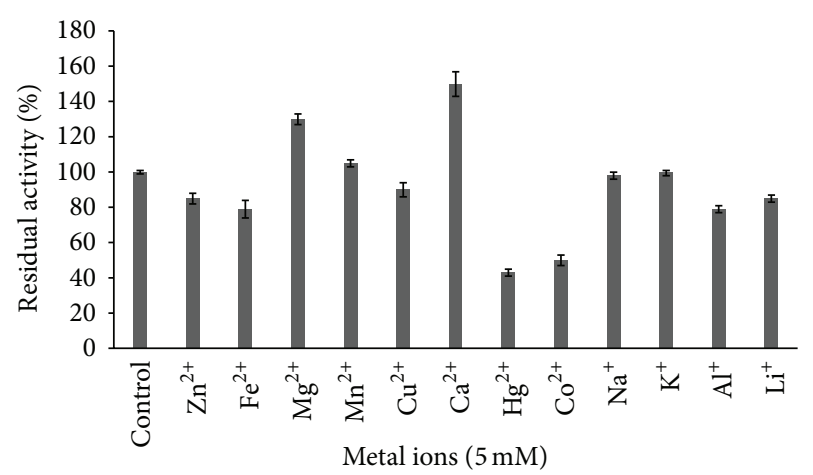

FIGURE 10: Effect of monovalent and bivalent ions on protease activity.

This was similar to result of protease from Geobacillus sp. YMTC 1049 [32]. It has been reported that serine proteases, such as subtilisin, have $\mathrm{Ca}^{2+}$ binding sites, and their stability at higher temperatures was explained by the strengthening of interactions inside protein molecules and the better stabilization of active site against thermal denaturation [33].

The enzyme was quite stable with $\mathrm{Mn}^{2+}, \mathrm{K}^{+}, \mathrm{Na}^{+}, \mathrm{Zn}^{2+}$, $\mathrm{Fe}^{2+}, \mathrm{Cu}^{2+}, \mathrm{Al}^{+}$, and $\mathrm{Li}^{+}$at $5 \mathrm{Mm}$. The repressive effect of $\mathrm{Zn}^{2+}$ and $\mathrm{Cu}^{2+}$ was reported earlier [2, 34]. Metals like $\mathrm{Hg}^{2+}$ and $\mathrm{Co}^{2+}$ strongly inhibit the activity compared to control.

3.5.3. Effect of Detergents on Enzyme Activity. All tested detergents did not inhibit protease activity but rather an enhancement was observed with SDS and CTAB (increasing activity by 20 and $10 \%$, resp.). This result is consistent with those reported for alkaline proteases from Bacillus sp. and Bacillus clausii $[35,36]$. In addition, the protease produced by Geobacillus toebii LBT 77 was also compatible with commercial detergents like OMO, Nadhif, and Ariel (Figure 11).

3.5.4. Effect of Organic Solvents on Protease Stability. The effect of various organic solvents at 25 and $50 \%(\mathrm{v} / \mathrm{v})$ on

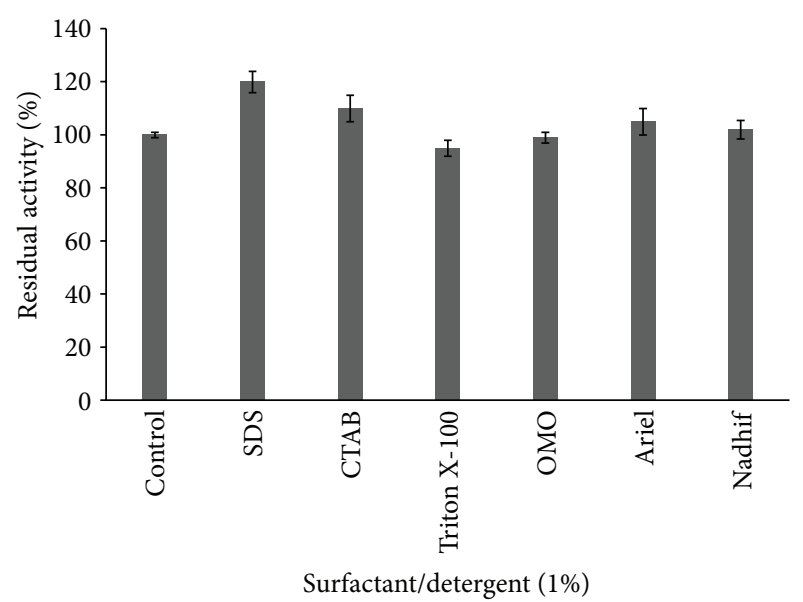

FIGURE 11: Effect of surfactants and detergents on protease activity.

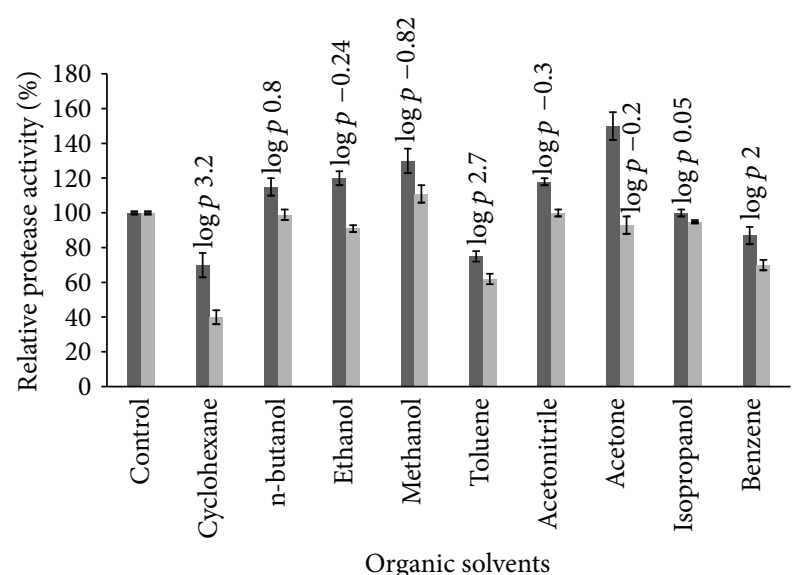

FIGURE 12: Effect of organic solvents on protease activity.

protease stability is shown in Figure 12. Protease activity was increased in the presence of acetonitrile, methanol, ethanol, and n-butanol at $25 \% \mathrm{v} / \mathrm{v}$. A similar result was reported for the protease produced by Bacillus sp. EMB9 [9]. The most interesting observation is that the activity remains stable with acetone (93\% of activity) unlike protease from Bacillus sp. EMB9 which retains only $20 \%$ of its initial activity [9]. Activity was stable with isopropanol, acetonitrile, and nbutanol at $50 \% \mathrm{v} / \mathrm{v}$. There is a small decrease in activity in the presence of $50 \%$ ethanol (91\% of activity).

The enzyme keeps 70,62 , and $40 \%$ of its activity in the presence of $50 \%$ benzene, toluene, and cyclohexane, respectively. Protease from Geobacillus toebii LBT 77 was found stable in solvents concentration $50 \%$ even after $4 \mathrm{~h}$ at $55^{\circ} \mathrm{C}$. This was found to be superior stability compared to protease characterized from Bacillus sp. and Bacillus sp. EMB9 which retain only about $20 \%$ of their activity $[2,9]$.

3.6. Catalytic and Thermodynamic Parameters. Thermodynamic and kinetic parameters shown in Table 2 confirm the high interest of the enzyme. Actually, catalytic efficiency of the serine protease from LBT $77\left(99 \mathrm{mg} \mathrm{mL}^{-1} \mathrm{~S}^{-1}\right)$ is better 
TABLE 2: Kinetic and thermodynamic parameters of the purified enzyme.

\begin{tabular}{lccc}
\hline \multicolumn{1}{c}{ Kinetic parameters } & \multicolumn{2}{c}{ Thermodynamic parameters } \\
\hline$K_{m}(\mathrm{mg} / \mathrm{mL})$ & 1 & $E_{a}\left(\mathrm{~kJ} \mathrm{~mol}^{-1}\right)$ & 51.5 \\
$V_{\max }(\mathrm{U} / \mathrm{mL})$ & 217.5 & $\Delta H^{*}\left(\mathrm{~kJ} \mathrm{~mol}^{-1}\right)$ & 5 \\
$K_{\text {cat }}\left(\mathrm{S}^{-1}\right)$ & 94.5 & $\Delta S^{*}\left(\mathrm{~J} \mathrm{~mol}^{-1}\right)$ & -229 \\
$K_{\text {cat }} / K_{m}\left(\mathrm{mg} \mathrm{mL}^{-1} \mathrm{~S}^{-1}\right)$ & 99 & $\Delta G^{*}\left(\mathrm{~kJ} \mathrm{~mol}^{-1}\right)$ & 56.5 \\
\hline
\end{tabular}

than those of Bacillus pumilis CBS [21] and Halobacterium spl(1) [17] with 45 and $85 \mathrm{mg} \mathrm{mL}^{-1} \mathrm{~S}^{-1}$, respectively.

Briefly, the present study demonstrated that the purified serine protease from the thermophilic Geobacillus toebii strain LBT 77 has a number of properties that make it a promising potential candidate for application in the detergent industry as a bioadditive in detergent formulation. In fact, it showed high levels of thermoactivity and thermostability and a marked stability to detergents. The enzyme also exhibited high levels of stability against $\mathrm{pH}, \mathrm{NaCl}$, ions, detergents, and solvent which responds to the industrial requirements.

\section{Competing Interests}

The authors declare that they have no competing interests.

\section{Acknowledgments}

This work was funded by the Tunisian Ministry of Higher Education and Scientific Research.

\section{References}

[1] R. M. Banik and M. Prakash, "Laundry detergent compatibility of the alkaline protease from Bacillus cereus," Microbiological Research, vol. 159, no. 2, pp. 135-140, 2004.

[2] D. Jain, I. Pancha, S. K. Mishra, A. Shrivastav, and S. Mishra, "Purification and characterization of haloalkaline thermoactive, solvent stable and SDS-induced protease from Bacillus sp.: a potential additive for laundry detergents," Bioresource Technology, vol. 115, pp. 228-236, 2012.

[3] A. Gupta, I. Roy, R. K. Patel, S. P. Singh, S. K. Khare, and M. N. Gupta, "One-step purification and characterization of an alkaline protease from haloalkaliphilic Bacillus sp.", Journal of Chromatography A, vol. 1075, no. 1-2, pp. 103-108, 2005.

[4] A. Haddar, R. Agrebi, A. Bougatef, N. Hmidet, A. SellamiKamoun, and M. Nasri, "Two detergent stable alkaline serineproteases from Bacillus mojavensis A21: purification, characterization and potential application as a laundry detergent additive," Bioresource Technology, vol. 100, no. 13, pp. 3366-3373, 2009.

[5] M. Jacobs, M. Eliasson, M. Uhlén, and J.-I. Flock, "Cloning, sequencing and expression of subtilisin carlsberg from Bacillus licheniformis," Nucleic Acids Research, vol. 13, no. 24, pp. 89138926, 1985.

[6] A. Benkiar, Z. J. Nadia, A. Badis et al., "Biochemical and molecular characterization of a thermo- and detergent-stable alkaline serine keratinolytic protease from Bacillus circulans strain DZ100 for detergent formulations and feather-biodegradation process," International Biodeterioration and Biodegradation, vol. 83, pp. 129-138, 2013.

[7] B. Jaouadi, B. Abdelmalek, D. Fodil et al., "Purification and characterization of a thermostable keratinolytic serine alkaline proteinase from Streptomyces sp. strain AB1 with high stability in organic solvents," Bioresource Technology, vol. 101, no. 21, pp. 8361-8369, 2010.

[8] T. Maruthiah, P. Esakkiraj, G. Prabakaran, A. Palavesam, and G. Immanuel, "Purification and characterization of moderately halophilic alkaline serine protease from marine Bacillus subtilis AP-MSU 6," Biocatalysis and Agricultural Biotechnology, vol. 2, no. 2, pp. 116-119, 2013.

[9] R. Sinha and S. K. Khare, "Characterization of detergent compatible protease of a halophilic Bacillus sp. EMB9: differential role of metal ions in stability and activity," Bioresource Technology, vol. 145, pp. 357-361, 2013.

[10] X.-G. Chen, O. Stabnikova, J.-H. Tay, J.-Y. Wang, and S. T.L. Tay, "Thermoactive extracellular proteases of Geobacillus caldoproteolyticus, sp. nov., from sewage sludge," Extremophiles, vol. 8, no. 6, pp. 489-498, 2004.

[11] J. Marmur, "A procedure for the isolation of deoxyribonucleic acid from micro-organisms," Journal of Molecular Biology, vol. 3, no. 2, pp. 208-218, 1961.

[12] A. V. Piterina, J. Bartlett, and J. T. Pembroke, "Molecular analysis of bacterial community DNA in sludge undergoing autothermal thermophilic aerobic digestion (ATAD): pitfalls and improved methodology to enhance diversity recovery," Diversity, vol. 2, no. 4, pp. 505-526, 2010.

[13] D. Shrinivas and G. R. Naik, "Characterization of alkaline thermostable keratinolytic protease from thermoalkalophilic Bacillus halodurans JB 99 exhibiting dehairing activity," International Biodeterioration and Biodegradation, vol. 65, no. 1, pp. 29-35, 2011.

[14] M. M. Bradford, "A rapid and sensitive method for the quantitation of microgram quantities of protein utilizing the principle of protein-dye binding," Analytical Biochemistry, vol. 72, no. 1-2, pp. 248-254, 1976.

[15] U. K. Laemmli, F. Beguin, and G. Gujer-Kellenberger, "A factor preventing the major head protein of bacteriophage T4 from random aggregation," Journal of Molecular Biology, vol. 47, no. 1, pp. 69-85, 1970.

[16] F. L. Garcia-Carreno, L. E. Dimes, and N. F. Haard, "Substrategel electrophoresis for composition and molecular weight of proteinases or proteinaceous proteinase inhibitors," Analytical Biochemistry, vol. 214, no. 1, pp. 65-69, 1993.

[17] A. V. Akolkar and A. J. Desai, "Catalytic and thermodynamic characterization of protease from Halobacterium sp. SP1(1)," Research in Microbiology, vol. 161, no. 5, pp. 355-362, 2010.

[18] A. Khan, K. Williams, M. P. Molloy, and H. Nevalainen, "Purification and characterization of a serine protease and chitinases from Paecilomyces lilacinus and detection of chitinase activity on 2D gels," Protein Expression and Purification, vol. 32, no. 2, pp. 210-220, 2003.

[19] P. Shivanand and G. Jayaraman, "Production of extracellular protease from halotolerant bacterium, Bacillus aquimaris strain VITP4 isolated from Kumta coast," Process Biochemistry, vol. 44, no. 10, pp. 1088-1094, 2009.

[20] L. Lama, I. Romano, V. Calandrelli, B. Nicolaus, and A. Gambacorta, "Purification and characterization of a protease produced by an aerobic haloalkaliphilic species belonging to the Salinivibrio genus," Research in Microbiology, vol. 156, no. 4, pp. 478-484, 2005. 
[21] B. Jaouadi, S. Ellouz-Chaabouni, M. Rhimi, and S. Bejar, "Biochemical and molecular characterization of a detergent-stable serine alkaline protease from Bacillus pumilus CBS with high catalytic efficiency," Biochimie, vol. 90, no. 9, pp. 1291-1305, 2008.

[22] A. Haddar, A. Bougatef, R. Agrebi, A. Sellami-Kamoun, and M. Nasri, "A novel surfactant-stable alkaline serine-protease from a newly isolated Bacillus mojavensis A21. Purification and characterization," Process Biochemistry, vol. 44, no. 1, pp. 29-35, 2009.

[23] K. Adinarayana, P. Ellaiah, and D. Prasad, "Purification and partial characterization of thermostable serine alkaline protease from a newly isolated Bacillus subtilis PE-11," AAPS PharmSciTech, vol. 4, pp. 440-448, 2003.

[24] M. Lagzian and A. Asoodeh, "An extremely thermotolerant, alkaliphilic subtilisin-like protease from hyperthermophilic Bacillus sp. MLA64," International Journal of Biological Macromolecules, vol. 51, no. 5, pp. 960-967, 2012.

[25] Q. K. Beg and R. Gupta, "Purification and characterization of an oxidation-stable, thiol-dependent serine alkaline protease from Bacillus mojavensis," Enzyme and Microbial Technology, vol. 32, no. 2, pp. 294-304, 2003.

[26] H.-S. Joo and C.-S. Chang, "Production of protease from a new alkalophilic Bacillus sp. I-312 grown on soybean meal: optimization and some properties," Process Biochemistry, vol. 40, no. 3-4, pp. 1263-1270, 2005.

[27] N. Hmidet, N. El-Hadj Ali, A. Haddar, S. Kanoun, S.-K. Alya, and M. Nasri, "Alkaline proteases and thermostable $\alpha$-amylase co-produced by Bacillus licheniformis NH1: characterization and potential application as detergent additive," Biochemical Engineering Journal, vol. 47, no. 1-3, pp. 71-79, 2009.

[28] A. Deng, J. Wu, Y. Zhang, G. Zhang, and T. Wen, "Purification and characterization of a surfactant-stable high-alkaline protease from Bacillus sp. B001," Bioresource Technology, vol. 101, no. 18, pp. 7100-7106, 2010.

[29] N. Annamalai, M. V. Rajeswari, and T. Balasubramanian, "Extraction, purification and application of thermostable and halostable alkaline protease from Bacillus alveayuensis CAS 5 using marine wastes," Food and Bioproducts Processing, vol. 92, no. 4, pp. 335-342, 2014.

[30] A. Gessesse, "The use of nug meal as a low-cost substrate for the production of alkaline protease by the alkaliphilic Bacillus $s p$. AR-009 and some properties of the enzyme," Bioresource Technology, vol. 62, no. 1-2, pp. 59-61, 1997.

[31] K. Jellouli, O. Ghorbel-Bellaaj, H. B. Ayed, L. Manni, R. Agrebi, and M. Nasri, "Alkaline-protease from Bacillus licheniformis MP1: purification, characterization and potential application as a detergent additive and for shrimp waste deproteinization," Process Biochemistry, vol. 46, no. 6, pp. 1248-1256, 2011.

[32] W. Zhu, D. Cha, G. Cheng, Q. Peng, and P. Shen, "Purification and characterization of a thermostable protease from a newly isolated Geobacillus sp. YMTC 1049," Enzyme and Microbial Technology, vol. 40, no. 6, pp. 1592-1597, 2007.

[33] J. J. Hyeung, C. K. Byoung, R. P. Yu, and S. K. Yu, "A novel subtilisin-like serine protease from Thermoanaerobacter yonseiensis $\mathrm{KB}-1$ : its cloning, expression, and biochemical properties," Extremophiles, vol. 6, no. 3, pp. 233-243, 2002.

[34] B. Sana, D. Ghosh, M. Saha, and J. Mukherjee, "Purification and characterization of a salt, solvent, detergent and bleach tolerant protease from a new gamma-Proteobacterium isolated from the marine environment of the Sundarbans," Process Biochemistry, vol. 41, no. 1, pp. 208-215, 2006.
[35] R. K. Patel, M. S. Dodia, R. H. Joshi, and S. P. Singh, "Purification and characterization of alkaline protease from a newly isolated haloalkaliphilic Bacillus sp.", Process Biochemistry, vol. 41, no. 9, pp. 2002-2009, 2006.

[36] H.-S. Joo, C. G. Kumar, G.-C. Park, S. R. Paik, and C.-S. Chang, "Oxidant and SDS-stable alkaline protease from Bacillus clausii I-52: production and some properties," Journal of Applied Microbiology, vol. 95, no. 2, pp. 267-272, 2003. 

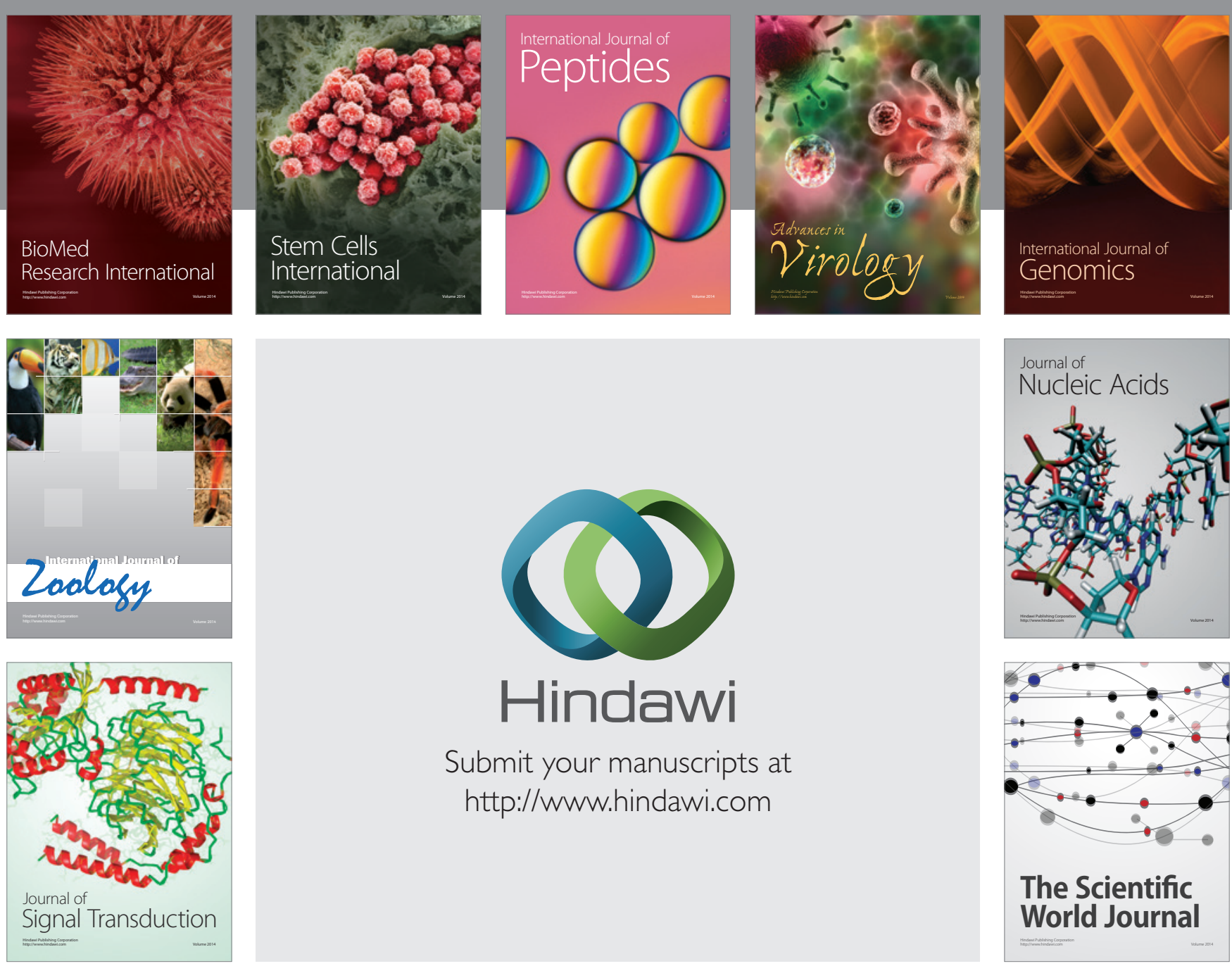

Submit your manuscripts at

http://www.hindawi.com
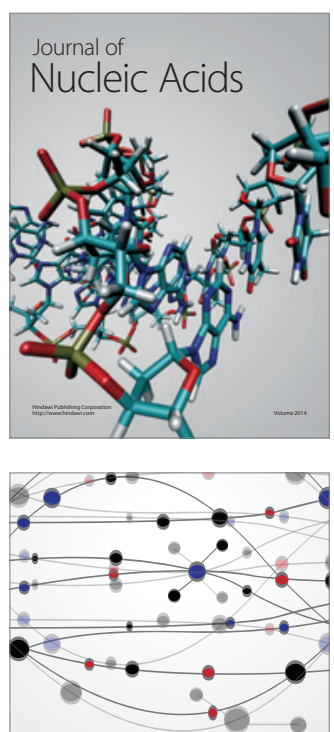

The Scientific World Journal
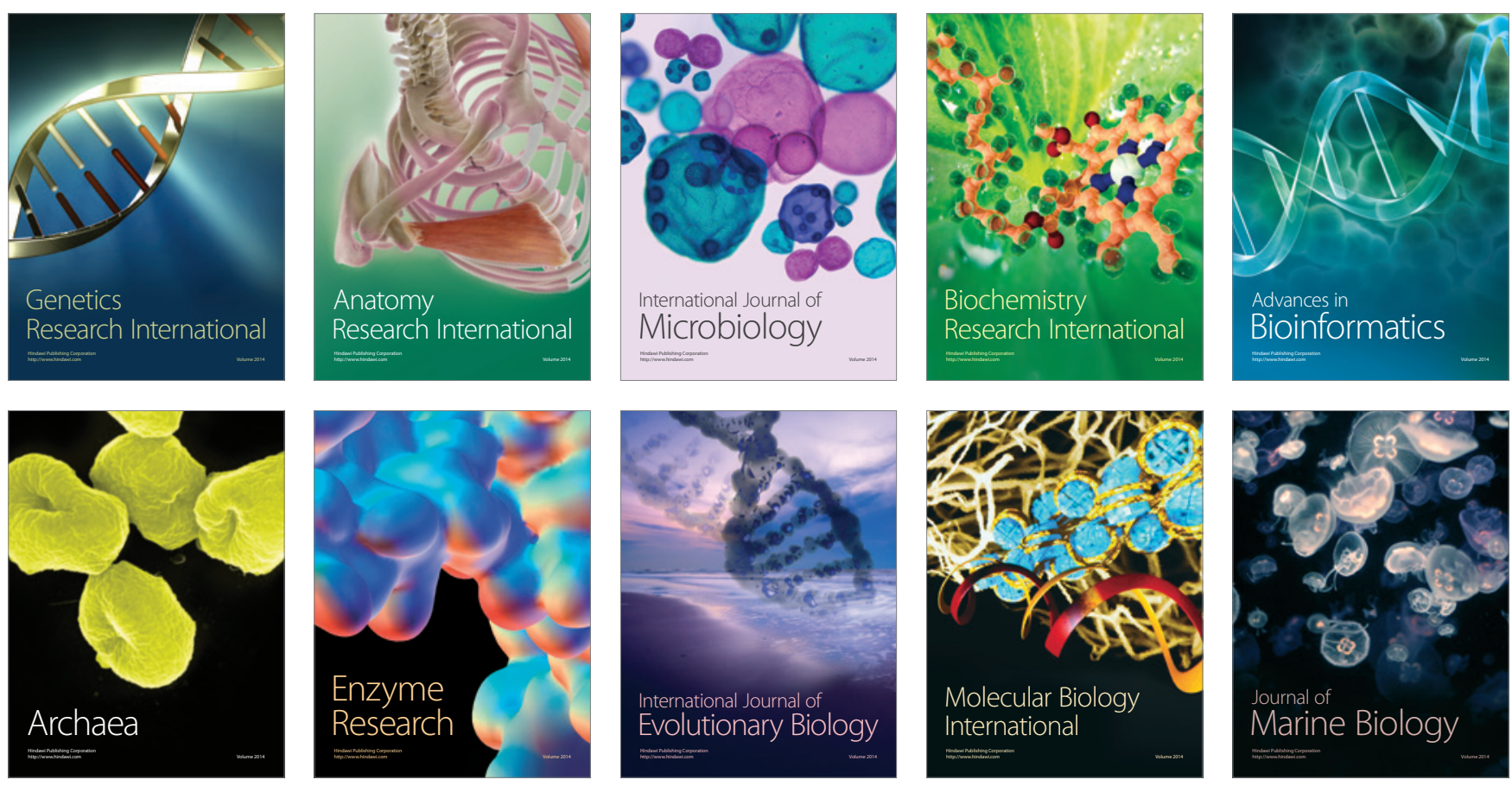